\title{
Consultatievoorstel wettelijke kwaliteitsrekening financiële ondernemingen: naar een praktisch alternatief voor een stichting derdengelden?
}

\author{
Prof. mr. W.A.K. Rank*
}

\begin{abstract}
1 Inleiding
Nadat de Autoriteit Financiële Markten (AFM) en De Nederlandsche Bank (DNB) in hun wetgevingsbrieven meermalen gepleit hebben voor de invoering van een wettelijke kwaliteitsrekening voor bepaalde financiële ondernemingen, heeft het Ministerie van Financiën - in samenwerking met de AFM en DNB - een daartoe strekkend conceptwetsvoorstel met bijbehorende concept-memorie van toelichting opgesteld. Dit conceptwetsvoorstel vormt een onderdeel van het conceptwetsvoorstel voor een Wijzigingswet financiële markten 2022 en is van 8 november 2020 tot 18 december 2020 voorwerp van een publieke consultatie geweest. De concepten zijn bedoeld om uit te monden in een wetsvoorstel dat na parlementaire behandeling in juli 2022 in werking zou moeten treden als onderdeel van de Wijzigingswet financiële markten 2022.
\end{abstract}

Het conceptwetsvoorstel maakt het voor betaalinstellingen, elektronischgeldinstellingen (EGI's) en beleggingsondernemingen mogelijk om op een alternatieve manier te voldoen aan de voor hen geldende verplichting tot afscheiding van voor derden gehouden geldmiddelen. Ook voor afwikkelondernemingen biedt het conceptwetsvoorstel deze mogelijkheid. De gewenste afscheiding kan worden bewerkstelligd door deze geldmiddelen aan te houden op een kwaliteitsrekening. Voor betaalinstellingen, EGI's en beleggingsondernemingen moet deze kwaliteitsrekening worden geopend bij een bank in Nederland. Voor afwikkelondernemingen moet zij worden geopend bij DNB. Uit de tenaamstelling moet blijken dat de rekening door de financiële onderneming wordt aangehouden in eigen naam ten behoeve van een of meer derden, met vermelding van de hoedanigheid van de rekeninghouder. De geld-

\footnotetext{
Prof. mr. W.A.K. Rank is hoogleraar Financieel Recht aan de Universiteit Leiden, Of Counsel bij NautaDutilh te Amsterdam en redacteur van dit tijdschrift.
}

middelen op deze rekening vormen een afgescheiden vermogen dat uitsluitend dient tot voldoening van vorderingen van (1) de bank waarbij de rekening wordt aangehouden c.q. $\mathrm{DNB}$, voor zover het gaat om vorderingen die verband houden met het beheer van de rekening, en (2) derden voor wie geldmiddelen op de rekening zijn bijgeschreven.

In dit artikel wordt onderzocht wat de toegevoegde waarde van de voorgestelde regeling is. Gaat het bij de wettelijke kwaliteitsrekening om een 'need-to-have' instrument of slechts om een 'nice-to-have' constructie? Wat zullen de gevolgen voor de praktijk zijn? Met het oog hierop wordt in het artikel ingegaan op de achtergrond, opzet en inhoud van de voorgestelde regeling. Daarbij wordt ook aandacht besteed aan de gekozen juridische constructie. Verder worden enkele praktische aspecten belicht. Om de materie in het juiste perspectief te kunnen plaatsen begint het artikel met een korte beschouwing over vermogensscheiding in het algemeen: Wat is vermogensscheiding? Welke (financiële en niet-financiële) marktpartijen zijn verplicht tot vermogensscheiding? Op welke manieren kan of moet vermogensscheiding worden gerealiseerd? En wat is de huidige praktijk ${ }^{1}$ Het artikel wordt afgesloten met een conclusie. $^{2}$

1. Zie nader over vermogensscheiding, in het bijzonder in de financiële sec tor, W.A.K. Rank, Vermogensscheiding: a bird's eye overview, in: W.A.K. Rank (red.), Vermogensscheiding in de financiële praktijk (Financieel Juridische Reeks, deel 14), Zutphen: Uitgeverij Paris 2018, p. 11-60, en de daar vermelde andere literatuur en jurisprudentie.

2. Schrijver dezes heeft, tezamen met prof. mr. M. Haentjens, het Ministerie van Financiën, DNB en de AFM geadviseerd over een eerdere versie van het conceptwetsvoorstel. Daarbij zijn ons geen publicatiebeperkingen opgelegd. De in deze bijdrage in par. 4.1-4.4 opgenomen kanttekeningen zijn ontleend aan, gebaseerd op of geïnspireerd door deze advisering en reflecteren derhalve in belangrijke mate - maar niet in alle opzichten onze gezamenlijke gedachtenvorming. 


\section{Vermogensscheiding}

\subsection{Wat is vermogensscheiding?}

Vermogensscheiding betreft het zodanig afscheiden van de activa van derden - gelden of financiële instrumenten - van de eigen activa van de persoon die deze activa onder zich heeft - een financiële onderneming, een advocaat, een notaris - dat (andere) crediteuren van die persoon zich daarop niet kunnen verhalen in het geval van insolventie van die persoon. $\mathrm{Bij}$ vermogensscheiding gaat het steeds om juridische segregatie. In het geval van juridische segregatie zijn de voor een derde gehouden waarden vermogensrechtelijk afgescheiden van de waarden van de persoon die de activa onder zich heeft en mogelijk ook van die van andere derden voor wie deze persoon activa onder zich heeft. De waarden behoren dan in juridische zin toe aan de derde of zijn uitsluitend vatbaar voor verhaal door de derde, en zijn niet vatbaar voor verhaal door (andere) crediteuren van de houder. Als de activa op naam van de houder worden aangehouden of geregistreerd of, waar het roerende zaken betreft, niet individualiseerbaar door hem worden bewaard, zal de houder, bij gebreke van een dergelijke afscheiding, als eigenaar van deze activa worden aangemerkt, met als gevolg dat zij in het geval van zijn insolventie in de failliete boedel vallen. ${ }^{3}$

Juridische segregatie moet worden onderscheiden van administratieve segregatie. In het geval van administratieve segregatie zijn de voor een derde gehouden activa alleen operationeel afgescheiden van de posities van de houder van de activa en mogelijk ook van die van andere derden. Overigens is administratieve segregatie niet zelden een voorwaarde voor juridische segregatie. Om juridische afscheiding mogelijk te maken zal de houder zijn administratie immers op een zodanige wijze moeten voeren dat daaruit blijkt welke financiële instrumenten en gelden voor welke derden worden gehouden. De houder van de activa zal dan verplicht zijn om alle gegevens bij te houden die noodzakelijk zijn om hem op elk moment in staat te stellen de activa die voor een derde worden gehouden te onderscheiden van voor andere derden gehouden activa en van zijn eigen activa, bijvoorbeeld door het openen van verschillend getitelde (grootboek)rekeningen in zijn administratie. In bepaalde jurisdicties zal administratieve segregatie van rechtswege in juridische segregatie resulteren. Het boeken van gelden of financiële instrumenten in verschillend getitelde rekeningen leidt dan automatisch tot vermogensscheiding. In Nederland is dat niet het geval.

\subsection{Welke marktpartijen zijn verplicht tot vermogensscheiding?}

De Nederlandse financiële toezichtwetgeving bevat gedetailleerde regels inzake de door financiële ondernemingen toe te passen vermogensscheiding bij het houden van financiële instrumenten en gelden van cliënten. Het gaat hier om regels

3. Vgl. art. 3:109 jo. art. 3:119 BW en HR 12 januari 1968, ECLI:NL:HR: 1968:AC2286, NJ 1968/274 (Mulder c.s./c.v. Gebr. Teixeira de Mattos c.s.). van toezichtrecht die strekken tot het bereiken van een bepaald civielrechtelijk gevolg, namelijk dat activa van cliënten zodanig zijn afgescheiden van het vermogen van de financiële onderneming dat (andere) crediteuren van de financiële onderneming (dan de rechthebbenden) zich daarop niet kunnen verhalen. Hoofddoel is steeds bescherming tegen het tussenpersoonrisico, het zogenaamde intermediary risk. ${ }^{4}$ De voorschriften verschillen al naar gelang het type instelling en de aard van de activa. Wel streven de wetgever en de toezichthouders ernaar om de voorschriften voor de verschillende typen financiële ondernemingen gelijk te trekken.

In de financiële sector gelden voorschriften inzake vermogensscheiding - juridische segregatie - voor (bank)beleggingsondernemingen, beleggingsinstellingen (ABI's en ICBE's), premiepensioeninstellingen (PPI's), algemeen pensioenfondsen (APF's), betaalinstellingen en EGI's. Daarnaast gelden er administratieve segregatieverplichtingen voor centrale tegenpartijen (Central Counterparties; CCPs), clearing members (CMs) en centrale effectenbewaarinstellingen (Central Securities Depositaries; CSDs). ${ }^{5}$ Buiten de financiële sector bestaan er regels inzake vermogensscheiding voor notarissen, gerechtsdeurwaarders en advocaten. ${ }^{6}$ In de meeste gevallen schrijven de toepasselijke regels precies voor hoe de beoogde vermogensscheiding moet worden gerealiseerd. In een enkel geval is de regelgeving louter functioneel en is er geen specifieke wijze van vermogensscheiding voorgeschreven. Dan is het aan partijen om zelf een wijze van vermogensscheiding te kiezen.

\subsection{Mogelijke constructies vermogensscheiding}

We beschikken in Nederland niet over de figuur van de trust. Bij een dergelijke figuur vallen de activa niet in het vermogen van degene die daarvan de juridische eigendom heeft, maar in het vermogen van de (economisch) belanghebbende. Daarom zijn er naar Nederlands recht bepaalde constructies nodig om vermogensscheiding van niet-geïndividualiseerde activa te realiseren. Mogelijke constructies die in dit verband wel worden toegepast, zijn de vestiging van een pandrecht op de activa ten behoeve van de belanghebbenden tot zekerheid van de rechten van deze belanghebbenden met betrekking tot deze activa, of een regeling die de belanghebbende bij faillissement van de tussenpersoon de mogelijkheid geeft de rechten die de tussenpersoon ter zake van de activa jegens een derde heeft op de belanghebbende te doen overgaan. ${ }^{7}$ De meest gebruikelijke - en door de wetgever als geldig erkende - constructies die in dit verband worden gehanteerd, zijn echter:

a. het onderbrengen van de activa in een aparte (bewaar)instelling; en

b. het creëren van een afgescheiden vermogen.

4. Zie over intermediary risk in breed verband S.L. Schwarcz, Intermediary Risk in a Global Economy, Duke Law Journal (50) 2001, afl. 6, p. 1541-1607.

5. Zie voor deze voorschriften en hun vindplaats par. 2.4 hierna.

6. Zie voor deze voorschriften en hun vindplaats par. 2.4 hierna.

7. Vgl. art. 7:19 Nrgfo Wft en art. 7:420 BW. 
Dat afgescheiden vermogen kan een vermogen zijn dat toebehoort aan de (gezamenlijke) belanghebbenden, of een vermogen dat toebehoort aan de houder van de activa waarop alleen bepaalde crediteuren zich kunnen verhalen (verhaalsvermogen).

Voor het creëren van een afgescheiden vermogen is volgens het ProCall-arrest van de Hoge Raad in beginsel een wettelijke regeling nodig, zoals art. 25 Wet op het notarisambt (Wna) respectievelijk art. 19 Gerechtsdeurwaarderswet (GDW) voor notarissen en gerechtsdeurwaarders voorziet in een kwaliteitsrekening waarvan het saldo toekomt aan de gezamenlijke clienten van de notaris respectievelijk de deurwaarder in plaats van aan de notaris respectievelijk de deurwaarder. ${ }^{8}$ De keerzijde van vermogensscheiding - het apart zetten van bepaalde vermogensbestanddelen ten behoeve van bepaalde crediteuren, activabeklemming - is immers dat er inbreuk wordt gemaakt op twee belangrijke vermogensrechtelijke principes, te weten (1) het principe dat een schuldeiser zijn vordering op alle goederen van zijn schuldenaar kan verhalen (art. 3:276 $\mathrm{BW}$ ), en (2) de paritas creditorum, het beginsel dat schuldeisers onderling een gelijk recht hebben om zich naar evenredigheid van hun vordering op de goederen van hun schuldenaar te verhalen (art. 3:277 BW). Overeenkomstige toepassing van art. 25 Wna en art. 19 GDW is volgens de Hoge Raad in het ProCall-arrest dan ook alleen mogelijk met betrekking tot beroepsgroepen die wat betreft derdengelden een met de notaris vergelijkbare vertrouwensfunctie vervullen, zoals advocaten en accountants.

In lijn hiermee heeft de Hoge Raad in zijn arrest van 23 juni 2017 art. 25 Wna en art. 19 GDW van overeenkomstige toepassing geacht op een door een stichting derdengelden advocatuur aangehouden bankrekening en aangenomen dat een banksaldo ten name van een dergelijke stichting toebehoort aan de gezamenlijke cliënten van het advocatenkantoor, een en ander naar evenredigheid van de ten behoeve van deze cliënten gestorte bedragen, en niet aan de stichting. ${ }^{9}$ Recentelijk heeft de Hoge Raad dit standpunt nog eens herhaald bij wijze van obiter dictum. ${ }^{10}$ Gelet op de in het ProCall-arrest gegeven opmaat komt dit oordeel van de Hoge Raad niet als een totale verrassing. Opmerkelijk zijn deze arresten mijns inziens wel, omdat de Hoge Raad daarin twee te onderscheiden vormen van vermogensscheiding over één kam scheert zonder dat daarvoor een directe wettelijke basis bestaat en daarbij miskent dat de gelden bij insolventie van de advocaat daarom al niet in de failliete boedel vallen, omdat zij worden gehouden door de stichting derdengelden - een aparte bewaarinstelling - en niet door de advocaat, een situatie die

8. HR 13 juni 2003, ECLI:NL:HR:2003:AF3413, NJ 2004/196 (Beatrix Ziekenhuis/ProCall).

9. HR 23 juni 2017, ECLI:NL:HR:2017:1139, NJ 2017/436 (St. Beheer Derdengelden Advocatuur NautaDutilh/Ontvanger).

10. In HR 19 juni 2020, ECLI:NL:HR:2020:1078, NJ 2020/407 (Schreurs en St. Trustaccount Boels Zanders/Rabobank). wezenlijk verschilt van die bij de notaris en de gerechtsdeurwaarder.

\subsection{Vermogensscheiding bij verschillende soorten instellingen}

Bij beleggingsondernemingen behoren op dit moment beide constructies tot de mogelijkheden: bewaring van activa van clienten via een separate (bewaar)instelling en de creatie van afgescheiden (verhaals)vermogens door het bewaren van de relevante activa conform de Wet giraal effectenverkeer (Wge). ${ }^{11}$ Bij beleggingsinstellingen voorziet de wet in de creatie van afgescheiden verhaalsvermogens. ${ }^{12}$ Hetzelfde geldt voor PPI's en APF's. ${ }^{13}$ Betaalinstellingen en EGI's zijn verplicht van betaaldienstgebruikers en andere betaaldienstverleners ontvangen gelden zeker te stellen. Voor EGI's geldt eenzelfde verplichting met betrekking tot gelden die worden of zijn ontvangen in ruil voor elektronisch geld. ${ }^{14} \mathrm{Bij}$ betaalinstellingen en EGI's is geen specifieke wijze van vermogensscheiding voorgeschreven. In de praktijk is hier altijd sprake van een aparte bewaarinstelling: een stichting derdengelden. Voor CCPs en CMs (en ook voor cliënten van CMs) gelden alleen administratieve segregatieverplichtingen. ${ }^{15}$ Hetzelfde geldt voor CSDs en aangesloten instellingen. ${ }^{16}$

De constructie van het afgescheiden vermogen vinden we ook bij notarissen en gerechtsdeurwaarders. Bij beide beroepsgroepen voorziet de wet in de creatie van een generale kwaliteitsrekening. Deze luidt op naam van de notaris respectievelijk de gerechtsdeurwaarder, maar het saldo behoort toe aan de gezamenlijke cliënten van de notaris respectievelijk de deurwaarder, waarbij elke cliënt een aandeel in dit saldo toekomt dat evenredig is met de door of ten behoeve van deze cliënt gestorte bedragen. De constructie van een aparte bewaarinstelling vinden we bij advocaten. Een advocaat dient ervoor te zorgen dat derdengelden worden overgemaakt naar een bankrekening op naam van een speciaal daarvoor opgerichte risicoaverse stichting derdengelden. ${ }^{17}$ Uit de door de Nederlandse Orde van Advocaten voorgeschreven modelstatuten voor een stichting derdengelden en de modelserviceovereenkomst die tussen het advocatenkantoor en een dergelijke stichting moet worden gesloten, blijkt dat het banksaldo toekomt aan de stichting en dat elke cliënt voor het hem toekomende bedrag een vordering op de stichting heeft. Vreemd genoeg lijkt de Hoge Raad dit

11. Zie art. 4:87 Wft, uitgewerkt in art. 165-165b BGfo Wft en art. 7:15-7:18 Nrgfo Wft resp. in art. 1-49 Wge (afgescheiden cliëntenvermogens in de vorm van verzamel- en girodepots voor effecten in de klassieke zin des woords) en art. 49f- 49h Wge (afgescheiden verhaalsvermogens voor derivatenposities).

12. Zie art. 4:37j lid $5 \mathrm{Wft}$ voor ABI's en art. 4:45 lid $1 \mathrm{Wft}$ voor ICBE's.

13. Zie art. 4:71a Wft voor PPI's resp. art. 123 lid 3 PW voor APF's.

14. Zie art. 3:29a Wft jo. art. 40a en $40 \mathrm{~b}$ Bpr Wft.

15. Zie art. 39 en 48 EMIR. Zie W.A.K. Rank, Segregatie en portabiliteit: de Wge als panacee voor MiFID en EMIR, MvV 2014, afl. 7/8, p. 214-223; W.A.K. Rank \& S. Uiterwijk, Voorgestelde wijziging segregatie EMIR een (ondoordacht) steuntje in de rug voor portabiliteit, FR 2017, p. 374-380.

16. Zie art. 38 CSDR.

17. Zie art. 6.19 jo. art. 6.21 Verordening op de Advocatuur. 
niet te (willen) onderkennen en gaat hij met voorbijgaan aan de bestaande contractuele regeling uit van een interpretatie waarin het saldo op de rekening toebehoort aan de gezamenlijke cliënten van de advocaat. ${ }^{18}$

\section{Conceptwetsvoorstel}

\subsection{Achtergrond en opzet}

Momenteel voldoen de meeste financiële ondernemingen aan hun verplichting tot afscheiding van voor derden gehouden geldmiddelen door middel van een separate bewaarinstelling, een stichting derdengelden. Volgens de concept-memorie van toelichting stuit een dergelijke constructie in het buitenland regelmatig op onbegrip. Buitenlandse partijen weigeren soms om aan een stichting derdengelden te betalen, omdat zij vrezen dat een betaling aan een ander dan de financiële onderneming niet bevrijdend zal zijn. Dit onbegrip en het feit dat het hier een jarenlange wens van de AFM en DNB betreft, zijn voor de wetgever een belangrijke reden om voor betaalinstellingen, EGI's, beleggingsondernemingen en afwikkelondernemingen de figuur van een wettelijke kwaliteitsrekening te introduceren. ${ }^{9}$

In het conceptwetsvoorstel wordt gekozen voor een wettelijke kwaliteitsrekening met een afgescheiden vermogen, dat wil zeggen een kwaliteitsrekening die door de desbetreffende financiële onderneming in eigen naam wordt aangehouden ten behoeve van een of meer belanghebbenden, waarbij de op de kwaliteitsrekening aangehouden gelden een afgescheiden vermogen vormen dat uitsluitend dient tot voldoening van bepaalde vorderingen van genoemde belanghebbende. De keuze voor deze figuur wordt in de concept-memorie van toelichting gerechtvaardigd door te refereren aan het feit dat de financiële toezichtwetgeving deze figuur al kent. In dit verband wordt verwezen naar art. 4:37j lid 5 en $4: 45$ lid $1 \mathrm{Wft}$ voor ABI's en ICBE's, art. 4:71a Wft voor PPI's, art. 123 Pensioenwet (PW) voor APF's en art. 46g lid 1 Wge voor tussenpersonen in derivaten. ${ }^{20}$ In genoemde bepalingen wordt voor elk van deze typen financiële ondernemingen voorzien in de creatie van een afgescheiden vermogen waarop alleen bepaalde vorderingen verhaald kunnen worden. Aldus bezien past deze figuur goed in het systeem van de financiële toezichtwetgeving en sluit zij aan bij andere in deze wetgeving geregelde gevallen. Volgens de concept-memorie van toelichting bevordert dit de crosssectorale uniformiteit van de financiële regelgeving en draagt dit bij aan de transparantie van die regelgeving. ${ }^{21}$

De in het conceptwetsvoorstel voorgestelde kwaliteitsrekening onderscheidt zich van de kwaliteitsrekening als bedoeld in art. 25 Wna en art. 19 GDW. Bij deze beide kwaliteitsreke-

\footnotetext{
18. HR 23 juni 2017, ECLI:NL:HR:2017:1139, NJ 2017/436 (St. Beheer Derdengelden Advocatuur NautaDutilh/Ontvanger) en HR 19 juni 2020, ECLI:NL:HR:2020:1078, NJ 2020/407 (Schreurs en St. Trustaccount Boels Zanders/Rabobank).

19. Concept-MvT, p. 1-2.

20. Concept-MvT, p. 2.

21. Concept-MvT, p. 2.
}

ningen behoort het saldo toe aan de gezamenlijke belanghebbenden en is er sprake van een gemeenschap. Bij de in het conceptwetsvoorstel voorgestelde kwaliteitsrekening behoort het saldo toe aan de rekeninghouder, maar kunnen alleen bepaalde crediteuren zich erop verhalen. ${ }^{22}$ De concept-memorie van toelichting signaleert dit verschil wel, maar legt niet uit waarom is gekozen voor deze variant en niet voor een wettelijke kwaliteitsrekening met een aan de gezamenlijke belanghebbenden toekomend saldo. Dat is extra jammer, omdat de Wge wat betreft de bewaring van andere financiële instrumenten dan derivaten is gebaseerd op een daarmee vergelijkbare constructie - verzameldepots en girodepots die aan de gezamenlijke belanghebbenden toekomen en een gemeenschap vormen -, en dus ook van andere vormen van afscheiding gezegd kan worden dat zij in de financiële toezichtwetgeving passen. Geheel consistent ten aanzien van de gekozen constructie is de wetgever trouwens niet: in art. 3:29aa lid 7 respectievelijk art. 3:29d lid 7 respectievelijk art. 4:87aa lid 7 $\mathrm{Wft}$ wordt met zoveel woorden gesproken van 'een aandeel in het saldo van de rekening' dat aan de derde zou toekomen. Dit wijst op een gemeenschapsconstructie zoals we die kennen bij de door een notaris of een gerechtsdeurwaarder aangehouden kwaliteitsrekening waarbij het saldo aan de gezamenlijke belanghebbenden toekomt. Het lijkt mij raadzaam deze formulering nog eens tegen het licht te houden om interpretatiediscussies te voorkomen.

Van belang is - dit staat gelukkig ook in de concept-memorie van toelichting ${ }^{23}$ - dat de bestaande wijzen van vermogensscheiding beschikbaar blijven. Partijen kunnen er dus ook voor kiezen om van de figuur van een stichting derdengelden gebruik te (blijven) maken. $\mathrm{Nu}$ in de advocatuur al jarenlang gebruik wordt gemaakt van een stichting derdengelden en deze constructie - uitzonderingen daargelaten - zonder problemen functioneert, lijkt dat een verstandige beslissing. Overigens blijkt uit een door Van Praag verricht empirisch onderzoek van recente datum dat er op dit moment zo'n veertig betaalinstellingen en EGI's zijn die aan de op hen rustende verplichting tot afscheiding van derdengelden voldoen door middel van een stichting derdengelden. ${ }^{24}$ Het zou buitengewoon triest zijn als al deze stichtingen derdengelden zouden moeten worden geliquideerd. Dit klemt temeer omdat deze figuur in de context van de advocatuur haar bruikbaarheid over de jaren heen dubbel en dwars heeft bewezen.

\subsection{Tekst en toelichting}

Het wetsvoorstel voorziet in invoeging van een aantal nieuwe artikelen in de Wft. De belangrijkste daarvan zijn art. 3:29aa voor betaalinstellingen en EGI's, art. 3:29d voor afwikkelondernemingen en art. 4:87aa voor beleggingsondernemingen. Art. 3:29aa wordt hierna in detail besproken. Art. 3:29d en

22. Concept-MvT, p. 2 en 14

23. Concept-MvT, p. 3.

24. Zie E.J. van Praag, PSD2: naar open banking en bankieren in een ecosysteem. Preadvies voor de Vereniging voor Financieel Recht 2020, Deventer: Wolters Kluwer 2020, p. 185 e.v. 
art. 4:87aa zijn nagenoeg identiek aan art. 3:29aa en komen alleen aan de orde voor zover zij daarvan afwijken.

Art. 3:29aa lid 1 bepaalt dat een betaalinstelling of EGI de door haar ontvangen geldmiddelen kan zeker stellen door die geldmiddelen aan te houden op een rekening die uitsluitend daarvoor is bestemd. Uit de concept-memorie van toelichting blijkt dat het ook mogelijk is om meerdere rekeningen met afgescheiden vermogen te openen. In dit verband valt te denken aan het openen van een aparte rekening voor een bepaalde cliënt, aan rekeningen in verschillende valuta of aan rekeningen bij meerdere banken om de risico's te mitigeren. ${ }^{25}$

Ingevolge art. 3:29aa lid 2 moet de rekening worden aangehouden bij een vergunninghoudende bank met zetel in Nederland. Deze beperking tot banken met zetel in Nederland vindt haar oorzaak hierin dat de wetgever wil voorkomen dat de goederenrechtelijke en verhaalsrechtelijke aspecten mogelijk niet aan Nederlands recht onderworpen zijn. ${ }^{26}$ Art. 3:29aa lid 2 bepaalt ook dat uit de tenaamstelling moet blijken dat de rekening door de betaalinstelling of EGI wordt aangehouden in eigen naam ten behoeve van een of meer derden, met vermelding van de hoedanigheid van de betaalinstelling of EGI. Uit de concept-memorie van toelichting kan worden opgemaakt dat de aanduiding 'inzake' in het hoofd van de rekening hiervoor voldoende is. ${ }^{27}$

Art. 3:29aa lid 3 bepaalt dat de op de rekening aangehouden geldmiddelen een afgescheiden vermogen vormen dat uitsluitend dient tot voldoening van vorderingen van (a) de bank waarbij de rekening wordt aangehouden, voor zover deze vorderingen verband houden met het beheer van de rekening en contractueel ten laste van het afgescheiden vermogen kunnen worden gebracht, en (b) derden voor wie geldmiddelen op de rekening zijn geadministreerd, voor zover deze vorderingen verband houden met het toevertrouwen van geldmiddelen aan de betaalinstelling of EGI. Het feit dat de rekening op naam staat van de betaalinstelling of EGI betekent volgens de concept-memorie van toelichting dat de rekening tot het vermogen van de betaalinstelling of EGI behoort en dus bij faillissement in beginsel deel uitmaakt van de failliete boedel. Er is echter sprake van verhaalsexclusiviteit: alleen de onder (a) en (b) genoemde crediteuren kunnen zich op het afgescheiden vermogen verhalen. Dat brengt mee dat de curator in geval van faillissement van de betaalinstelling of EGI bij de verdeling van het afgescheiden vermogen zijn medewerking zal moeten verlenen aan effectuering van de positie van de belanghebbenden. ${ }^{28}$ Art. 3:29aa lid 4 verplicht de betaalinstelling of EGI zorg te dragen voor een adequate administratie van het afgescheiden vermogen. Deze bepaling onderstreept weer eens dat administratieve segregatie een noodzakelijke voorwaarde voor juridische segregatie is.

\footnotetext{
25. Concept-MvT, p. 11.

26. Concept-MvT, p. 11.

27. Concept-MvT, p. 11.

28. Concept-MvT, p. 3 en 12.
}

Art. 3:29aa lid 5 voorziet in een rangregeling voor het geval dat de geldmiddelen op de rekening bij vereffening ontoereikend blijken te zijn. In dat geval hebben de hiervoor onder (a) genoemde vorderingen voorrang boven de hiervoor onder (b) genoemde vorderingen. Andere vorderingen zijn ingevolge art. 3:29aa lid 6 alleen op het afgescheiden vermogen verhaalbaar indien vaststaat dat voornoemde vorderingen zullen kunnen worden voldaan en dat in de toekomst dergelijke vorderingen niet meer zullen ontstaan. De facto zal dit alleen aan de orde zijn nadat het afgescheiden vermogen is vereffend en er een liquidatieoverschot is dat niet ten goede zal kunnen komen van de geprivilegieerde crediteuren.

Ten slotte bepaalt art. 3:29aa lid 7 dat de betaalinstelling of EGI een tekort in het afgescheiden vermogen terstond aanvult. Ingeval een tekort niet is aangevuld, keert de betaalinstelling of EGI volgens deze bepaling in geval van een verzoek van een derde als bedoeld in lid 3 onderdeel (b) om uitkering van zijn aandeel in het saldo slechts zoveel uit aan deze derde als in verband met de rechten van andere in dat onderdeel bedoelde derden mogelijk is. Zolang het tekort voortduurt, wordt het saldo dus naar evenredigheid van eenieders vordering verdeeld. Uit het feit dat de financiële onderneming gehouden is tot aanzuivering van een eventueel tekort, blijkt volgens de concept-memorie van toelichting dat het verhaalsrecht van de belanghebbenden niet is beperkt tot het saldo op de kwaliteitsrekening, maar dat de belanghebbenden een (rest)vordering hebben jegens de betaalinstelling of de EGI en dat zij in het geval van een tekort ook verhaal kunnen nemen op het overige vermogen van de betaalinstelling of de EGI. ${ }^{29}$

Art. 3:29aa lid 8 bepaalt dat bij of krachtens algemene maatregel van bestuur (AMvB) nadere regels kunnen worden gesteld met betrekking tot de inrichting, de administratie en het beheer van de rekening. Voor betaalinstellingen en EGI's moet in dit verband ook worden gedacht aan het aanpassen van art. 40a en 40b Besluit prudentiële regels Wft (Bpr Wft) om het voorgestelde art. 3:29aa aan te laten sluiten bij deze bepalingen. Dat ervoor is gekozen om het afgescheiden vermogen als zodanig op wetsniveau te regelen, wordt in de concept-memorie van toelichting gemotiveerd met een verwijzing naar het eerder in deze bijdrage genoemde ProCall-arrest van de Hoge Raad, volgens welk arrest een dergelijke uitzondering op het uitgangspunt van art. 3:276 BW alleen kan worden aanvaard als dit bij wet is bepaald. ${ }^{30}$

Art. 3:29d en 4:87aa zijn nagenoeg gelijkluidend aan art. 3:29aa en bepalen mutatis mutandis voor afwikkelondernemingen en beleggingsondernemingen wat art. 3:29aa voor betaalinstellingen en EGI's bepaalt. Ik zal deze artikelen hier dan ook niet integraal bespreken. Afwijkend is dat een afwikkelonderneming de door haar te openen kwaliteitsrekening dient aan te houden bij DNB en dat bij AMvB voorwaarden kunnen worden gesteld waaraan een afwikkelonderneming

29. Concept-MvT, p. 13

30. Concept-MvT, p. 3. 
moet voldoen om een dergelijke rekening te mogen openen (art. 3:29d lid 2 en 8). De concept-memorie van toelichting noemt in dit verband de voorwaarde dat de afwikkelonderneming moet voldoen aan de toelatingseisen van TARGET2NL. ${ }^{31}$ De afwikkelonderneming is sowieso een beetje een vreemde eend in de bijt, omdat, anders dan voor betaalinstellingen, EGI's en beleggingsondernemingen, voor afwikkelondernemingen geen wettelijke verplichting tot vermogensscheiding bestaat. Art. 11 van de Regeling DNB Afwikkelondernemingen Wft verplicht een afwikkelonderneming tot een adequate beheersing van het bewaargevingsrisico ten aanzien van haar eigen activa en die van haar deelnemers. ${ }^{32}$ Op grond van deze bepaling verwacht DNB van afwikkelondernemingen dat zij als onderdeel van een beheerste bedrijfsvoering zorg dragen voor het zeker stellen van in de uitoefening van hun bedrijf gehouden derdengelden. Dat is wat mij betreft een vrij magere basis voor het aannemen van een dergelijke verstrekkende verplichting. Het is zelfs de vraag of het eigenlijk wel de bedoeling is dat afwikkelondernemingen überhaupt derdengelden onder zich krijgen. Onder de definitie van afwikkeldiensten in art. 1:1 Wft vallen wel het doorzenden van betaalopdrachten en het salderen van vorderingen en verplichtingen van betaaldienstverleners uit hoofde van betaalopdrachten, maar niet het ontvangen van geldmiddelen van derden. Dat neemt niet weg dat het problemen kan voorkomen als er sprake is van een regeling voor afscheiding van dergelijke derdengelden voor het geval het houden daarvan toch aan de orde mocht zijn. ${ }^{33} \mathrm{Bij}$ invoering van het conceptwetsvoorstel zal met betrekking tot afwikkelondernemingen moeten worden voorzien in een aanpassing van de Regeling DNB Afwikkelondernemingen $\mathrm{Wft}$ en met betrekking tot beleggingsondernemingen in een aanpassing van art. 7:5-7:17 Nadere regeling gedragstoezicht financiële ondernemingen Wft (Nrgfo Wft).

Volgens de concept-memorie van toelichting kwalificeert het op naam van de financiële onderneming op de kwaliteitsrekening geadministreerde saldo als een deposito dat door de depositohouder op eigen naam doch ten behoeve van een derde wordt aangehouden als bedoeld in art. 29.02 lid 3 van het Besluit bijzondere prudentiële maatregelen, beleggerscompensatie en depositogarantie Wft (Bbpm Wft). Het gevolg is dat de derden ten behoeve van wie de geldmiddelen worden aangehouden voor de toepassing van het depositogarantiestelsel elk afzonderlijk als depositohouder worden aangemerkt en dat hun aanspraken worden gegarandeerd tot een bedrag van $€ 100.000$ per persoon bij faillissement van de bank waar de kwaliteitsrekening wordt aangehouden. ${ }^{34}$ Voorwaarde is wel dat de identiteit van deze derden kan worden vastgesteld voorafgaand aan het tijdstip waarop besloten is tot toepassing van het depositogarantiestelsel. Voldoende is daarvoor dat deze uit

31. Concept-MvT, p. 14.

32. Regeling DNB Afwikkelondernemingen Wft van 24 april 2014, Stcrt. 2 mei 2014, 12398.

33. Er zijn momenteel drie afwikkelondernemingen actief in Nederland: CCV Groep BV, equensWorldline SE en Mastercard Europe SA/NV.

34. Concept-MvT, p. 3. de administratie van de financiële onderneming blijkt en dat uit de administratie van de bank blijkt dat het om een inzakerekening gaat. ${ }^{35}$

\section{Kanttekeningen}

\subsection{Begrijpelijkheid, eenvoud en kosten}

In de eerste plaats kan men zich de vraag stellen of het inderdaad zo is dat een kwaliteitsrekening bij buitenlandse partijen op meer begrip kan rekenen dan een stichting derdengelden. Mijn ervaring is dat het fenomeen stichting derdengelden redelijk eenvoudig is uit te leggen aan buitenlandse partijen als men in dit verband het begrip 'nominee' ten tonele voert, terwijl juist het systeem van een kwaliteitsrekening door de juridische complexiteit ervan - wie is rechthebbende van het saldo, wie is beschikkingsbevoegd? - vaak veel vragen oproept. Waarschijnlijk is het gebruikmaken van een kwaliteitsrekening operationeel eenvoudiger dan het hanteren van een stichting derdengelden, maar in essentie komt het in beide constructies neer op het voeren van een adequate administratie. Natuurlijk vergt het oprichten van een stichting derdengelden notariële tussenkomst en vraagt het opstellen van een overeenkomst tussen de financiële onderneming en de stichting derdengelden wellicht enige advocatuurlijke assistentie. De kosten en het tijdsbeslag daarvan moeten echter niet worden overschat. Bovendien zullen er in het geval van een kwaliteitsrekening ook juridische documenten nodig zijn, zoals de overeenkomst met de bank waarbij de rekening wordt aangehouden. Dat neemt niet weg dat een wettelijke kwaliteitsrekening in de praktijk waarschijnlijk wel goedkoper zal zijn dan een stichting derdengelden, doordat allerlei steeds terugkerende kosten om de stichting derdengelden draaiende te houden niet hoeven te worden gemaakt. Voor een door een beleggingsonderneming onderhouden stichting derdengelden bestaat bovendien een eigen vermogenseis van ten minste $€ 50.000$. $^{36}$ Ook deze eis geldt uiteraard niet in het geval van een wettelijke kwaliteitsrekening.

\subsection{Beschermingsniveau}

Een volgende vraag die in dit verband rijst, is die naar het beschermingsniveau. Het is zeker niet zo dat de belanghebbenden met de constructie van een wettelijke kwaliteitsrekening geen enkel financieel risico lopen. Weliswaar dienen de geldmiddelen op de kwaliteitsrekening uitsluitend tot voldoening van de vorderingen van de bank waarbij de rekening wordt aangehouden en van degenen voor wie de geldmiddelen op de rekening zijn gestort, maar dat wil niet zeggen dat deze geldmiddelen altijd toereikend zullen zijn om deze vorderingen te voldoen. Evenals in het geval van een stichting derdengelden is het in het geval van een kwaliteitsrekening denkbaar dat de financiële onderneming in weerwil van haar wettelijke en contractuele verplichtingen over de geldmiddelen heeft beschikt, of dat geldmiddelen ten onrechte niet op de kwaliteitsreke-

35. Vgl. art. 2.1 DNB Beleidsregel Reikwijdte en Uitvoering Depositogarantiestelsel van 10 juli 2017, Stcrt. 21 juli 2017, 41453.

36. Zie art. 7:17 lid 2 onder $1 \mathrm{Nrgfo} \mathrm{Wft}$. 
ning zijn bijgeschreven. Het wetsvoorstel onderkent ook expliciet dat sprake kan zijn van een tekort op de kwaliteitsrekening en bepaalt niet voor niets dat de financiële onderneming een dergelijk tekort terstond moet aanzuiveren en dat er tot dat moment slechts pro rata mag worden uitbetaald.

Zoals uiteengezet in paragraaf 3.2 voor betaalinstellingen en EGI's hebben de belanghebbenden in het geval van een tekort een (rest)vordering jegens de financiële onderneming en kunnen zij in het geval van een tekort verhaal nemen op het overige vermogen van de financiële onderneming. ${ }^{37}$ In het conceptwetsvoorstel wordt aan deze restvordering echter geen bijzondere status of rang toegekend. De concept-memorie van toelichting zegt daar ook niets over. De conclusie moet dan ook zijn dat deze restvordering een concurrent karakter heeft en dat de belanghebbenden bij insolventie van de financiële onderneming met betrekking tot deze restvordering slechts het recht zullen hebben om op gelijke voet met andere ongesecureerde en ongeprivilegieerde schuldeisers uit de nettoopbrengst van de activa van de financiële onderneming te worden voldaan, dit naar evenredigheid van eenieders vordering. Omdat een tekort op de kwaliteitsrekening zich waarschijnlijk juist zal voordoen bij insolventie van de financiële onderneming moet de impact hiervan op de bescherming van de belanghebbenden niet worden onderschat.

Wat ontbreekt in het conceptwetsvoorstel zijn bepalingen die betrekking hebben op de dynamische kant van het proces en die zouden kunnen bijdragen aan het voorkomen van het ontstaan van een dergelijk tekort. Te denken valt in dit verband aan een bepaling dat de financiële onderneming ervoor moet zorgen dat geldmiddelen die met het oog op de door de financiële onderneming te verrichten werkzaamheden aan de financiële onderneming worden toevertrouwd onmiddellijk op de kwaliteitsrekening moeten worden bijgeschreven, en dat de financiële onderneming zorgt voor overboeking als gelden ten onrechte op de kwaliteitsrekening zijn ontvangen of juist op een andere rekening. In dit verband rijst ook de vraag of het mogelijk moet blijven, zoals thans voor betaalinstellingen en EGI's is geregeld in art. 40a respectievelijk art. $40 \mathrm{~b} \mathrm{Bpr} \mathrm{Wft}$, dat de geldmiddelen eerst na één werkdag respectievelijk na vijf werkdagen op een afzonderlijke rekening worden gestort in plaats van terstond na de ontvangst ervan. Voor beleggingsondernemingen bepaalt art. 165b lid 1 Besluit Gedragstoezicht financiële ondernemingen Wft (BGfo Wft) - dat de implementatie vormt van art. 4 MiFID II-Uitvoeringsrichtlijn - nu juist dat een beleggingsonderneming door haar ontvangen derdengelden onmiddellijk op een afzonderlijke rekening moet storten. Wat mij betreft zijn de termijnen van art. 40a respectievelijk art. $40 \mathrm{~b} \mathrm{Bpr} \mathrm{Wft}$ moeilijk te verenigen met het uitgangspunt dat geen vermenging met de geldmiddelen van andere crediteuren mag plaatsvinden. Daar staat echter tegenover dat art. 40a en 40b Bpr Wft de implementatie vormen van art. 10 PSD2 en art. 7 van de Herziene EGI-

37. Zie concept-MvT, p. 13. richtlijn en dat deze laatste artikelen doorstorting na één werkdag respectievelijk vijf werkdagen toelaten. ${ }^{38}$ Afwijking daarvan zou het voor veel betaalinstellingen en EGI's operationeel moeilijker maken en bovendien neerkomen op goldplating ten opzichte van de genoemde Europese richtlijnen.

Een andere mogelijkheid om het ontstaan van tekorten te voorkomen zou kunnen zijn dat de betrokken financiële ondernemingen het veiligstellen van gelden scheiden van de operationele geldstromen. Dat betekent in het geval van een betaalinstelling of EGI dat alle in- en uitgaande betalingen gewoon via de betaalinstelling of de EGI lopen en dat deze er tegelijkertijd voor zorgt dat er binnen de genoemde termijnen van één werkdag respectievelijk vijf werkdagen steeds voldoende saldo aanwezig is op een niet-operationele kwaliteitsrekening om de met de lopende betaalopdrachten gemoeide geldbedragen te dekken. De hoogte van dit saldo zou steeds gelijk moeten zijn aan ofwel het totale bedrag aan transacties dat de betaalinstelling of EGI onderhanden heeft, ofwel een maandgemiddelde met een opslag. Een dergelijke scheiding tussen operationele betaalstromen en veiliggestelde gelden zou het gemakkelijker maken voor betaalinstellingen en EGI's om gebruik te maken van de in art. $40 \mathrm{a}$ respectievelijk art. $40 \mathrm{~b} \mathrm{Bpr}$ Wft geboden mogelijkheid de derdengelden te beleggen in veilige, liquide activa met een lage risicograad. Een dergelijke scheiding tussen operationele middelen en veiliggestelde gelden lijkt mij bij beleggingsondernemingen minder goed toepasbaar omdat de derdengelden daar over het algemeen langer zullen uitstaan en de bedragen groter zullen zijn.

\subsection{Verhaalbare vorderingen}

Andere vorderingen dan de in art. 3:29aa lid 3 respectievelijk art. 3:29d lid 3 respectievelijk art. 4:87aa lid 3 onder (a) en (b) genoemde vorderingen kunnen niet op het afgescheiden vermogen worden verhaald, ook niet als de desbetreffende vorderingen door pand of een verrekeningsrecht zijn gedekt. Dit volgt uit genoemde artikelen, volgens welke het afgescheiden vermogen uitsluitend dient tot verhaal van genoemde vorderingen. Ofschoon de concept-memorie van toelichting expliciet vermeldt dat de rekeninghouder bij uitsluiting bevoegd is tot het beheer van en de beschikking over de kwaliteitsrekening, ${ }^{39}$ brengt de in genoemde bepalingen voorziene verhaalsexclusiviteit mijns inziens mee dat de financiële onderneming geen pandrechten mag vestigen op of verrekeningsrechten mag verlenen ten aanzien van het saldo op de kwaliteitsrekening ter securering van andere dan de genoemde vorderingen. ${ }^{40}$ Pandrechten of verrekeningsrechten ter securering van andere vorderingen zullen ofwel ongeldig zijn, ofwel door de wederpartij niet rechtsgeldig kunnen worden uitgeoefend. Dat betekent dat de banken die een kwaliteitsrekening in de boeken nemen hun algemene voorwaarden niet onver-

38. Zie hierover kritisch W.A.K. Rank \& M. Tomé, PSD2 and the Safeguarding of Clients' Funds, Butterworths Journal of International Banking and Financial Law 2020, afl. 9, p. 620-623.

39. Concept-MvT, p. 12.

40. Aldus ook Rank \& Tomé 2020 
kort op deze rekeningrelatie van toepassing zullen kunnen verklaren, waar deze algemene voorwaarden in de regel zullen voorzien in een ruimer pandrecht en verrekeningsrecht.

Zowel de vordering van de belanghebbende als die van de bank moet aan bepaalde eisen voldoen om op het afgescheiden vermogen te mogen worden verhaald. De vordering van de derde voor wie geldmiddelen op de rekening zijn geadministreerd, moet verband houden met het toevertrouwen van de geldmiddelen aan de financiële onderneming. Deze derde kan mijns inziens zowel de partij zijn waarvan de geldmiddelen afkomstig zijn als de partij waarvoor de geldmiddelen bestemd zijn, een begunstigde. Dat zal afhangen van de contractuele constellatie. Vorderingen van een dergelijke partij die geen verband houden met het toevertrouwen van de geldmiddelen aan de financiële onderneming - vorderingen uit volstrekt anderen hoofde - kunnen niet op het afgescheiden vermogen worden verhaald. Voor de vordering van de bank geldt een dubbele beperking: zij moet verband houden met het beheer van de rekening en volgens de overeenkomst tussen de bank en de financiële onderneming ten laste van het afgescheiden vermogen kunnen worden gebracht. Naar het lijkt zullen in elk geval onder beheerskosten vallen de vaste kosten voor het aanhouden van de rekening, het uitvoeren van overboekingsopdrachten, papieren rekeningafschriften, overschrijvingsformulieren, verzendenveloppen en wat dies meer zij. Onduidelijk is echter of ook negatieve rente of kosten van beleggingsdienstverlening hieronder zullen vallen. ${ }^{41} \mathrm{Om}$ problemen te voorkomen zullen de bank en de financiële onderneming hierover heldere afspraken moeten maken bij het openen van de rekening.

Het ligt daarbij in de rede dat aan het begrip kosten van beheer in het geval van een kwaliteitsrekening van een beleggingsonderneming een andere en ruimere betekenis mag worden toegekend dan in het geval van een kwaliteitsrekening van een betaalinstelling, EGI of afwikkelonderneming. Dat heeft te maken met het doel waarvoor de gelden worden aangehouden. Bij betaalinstellingen, EGI's of afwikkelondernemingen gaat het steeds om gelden die worden ontvangen in verband met het verlenen van betaaldiensten of afwikkeldiensten. Het gaat daarbij om gelden die bedoeld zijn om te worden doorbetaald en niet langer te worden aangehouden dan technisch en organisatorisch noodzakelijk is. De rol van de bank zal dan ook beperkt zijn tot het effectueren van betalingen op instructie van de rekeninghoudende financiële onderneming. De kosten die de bank bij het falen van de financiële onderneming onder de noemer kosten van beheer op de rekening zal kunnen verhalen, zullen dan ook navenant beperkt zijn. Bij beleggingsondernemingen gaat het om gelden die zijn ontvangen in verband met het verlenen van beleg-

41. Vgl. art. 40a en 40b Bpr Wft, op grond waarvan de zeker te stellen gelden door een betaalinstelling of een EGI mogen worden belegd in veilige, liquide activa met een lage risicograad, en art. 165b lid 1 BGfo Wft, op grond waarvan de gelden door een beleggingsonderneming mogen worden gestort op een rekening bij een erkend geldmarktfonds. gingsdiensten. Die gelden kunnen eveneens bestemd zijn om meteen te worden doorbetaald, maar zullen even zo vaak, zo niet vaker, bestemd zijn om te worden belegd of om als zekerheid te dienen (cash collateral). Zeker in het laatste geval is niet zonder meer duidelijk welke kosten wel als kosten van beheer van de rekening zullen kunnen worden aangemerkt, en welke niet.

Zo zal een beleggingsonderneming die door een belegger is ingeschakeld om te fungeren als tussenpersoon bij derivatentransacties, van deze belegger ontvangen gelden die strekken tot zekerheid van diens verplichtingen uit hoofde van deze transacties, op de kwaliteitsrekening moeten storten. Daaraan doet niet af dat deze gelden in het geval van een niet-professionele belegger niet tot zekerheid aan de beleggingsonderneming mogen worden overdragen, maar aan deze zullen moeten worden verpand. ${ }^{42}$ De vraag is vervolgens of, indien de bank waarbij de rekening wordt aangehouden tevens als clearing member voor de beleggingsonderneming fungeert, de vordering die zij uit hoofde van de met de cliëntpositie corresponderende positie in derivaten op de beleggingsonderneming heeft, bij een falen van de beleggingsonderneming onder de noemer kosten van beheer op het saldo van de kwaliteitsrekening zou mogen verhalen indien dat contractueel zo is afgesproken. Als het antwoord op die vraag bevestigend luidt, zou de beleggingsonderneming deze gelden ook aan de bank kunnen verpanden tot zekerheid van de met de cliëntpositie corresponderende positie in derivaten. Ik kan mij echter ook voorstellen dat met een dergelijke interpretatie het begrip kosten van beheer te zeer wordt opgerekt. In dat geval lijkt het voor de bank aantrekkelijker om de beleggingsonderneming cash collateral ten gunste van de bank te laten stellen via een gewone operationele rekening, een rekening waarvan het saldo door de beleggingsonderneming aan de bank kan worden verpand ter securering van alle vorderingen van de bank op de beleggingsonderneming, uit welken hoofde ook.

In het verlengde van het vorenstaande kan de vraag worden gesteld of het wenselijk is om de bank het recht te geven om vorderingen die verband houden met het beheer van de kwaliteitsrekening op het saldo van de rekening te verhalen met voorrang boven de derden voor wie geldmiddelen op de rekening zijn bijgeschreven. Hiertegen pleit dat de bank op die manier voldaan wordt uit geldmiddelen die niet voor haar bestemd zijn. Hiervoor pleit dat de derden profiteren van de werkzaamheden van de bank in het kader van het beheer van de rekening. Wat mij betreft gaat het hier om een praktische regel: banken zullen immers niet bereid zijn kwaliteitsrekenin-

42. Zie art. 4:89a lid $1 \mathrm{Wft}$, volgens welke bepaling een beleggingsonderneming geen financiëlezekerheidsovereenkomst tot overdracht als bedoeld in art. 7:51 onder b BW mag sluiten met een niet-professionele belegger met als doel om huidige of toekomstige verplichtingen van deze belegger, al dan niet voorwaardelijk, te waarborgen of af te dekken. Zie over dit verbod en de consequenties ervan voor de praktijk uitvoerig W.A.K. Rank \& S. Uiterwijk, Verbod op FZO tot overdracht onder MiFID II: van zekerheidseigendom naar pandrecht?, FR 2018, afl. 1/2, p. 39-46. 
gen aan te bieden als voldoening van hun vorderingen uit hoofde van het beheer daarvan niet gewaarborgd is.

\subsection{Effectueren van verhaal}

Het lijkt mij juist, gelijk in de concept-memorie van toelichting wordt gesteld, dat de verhaalsexclusiviteit meebrengt dat een curator in geval van faillissement van de financiële onderneming bij de verdeling medewerking moet verlenen aan effectuering van de positie van de belanghebbenden op het afgescheiden vermogen. ${ }^{43}$ Onzeker is wat mij betreft of in een dergelijk geval een afkoelingsperiode aan het effectueren van verhaal in de weg kan staan. De vraag is daarnaast hoe de belanghebbenden buiten de situatie van insolventie hun verhaal moeten effectueren. De concept-memorie van toelichting zegt daarover dat de belanghebbenden onder de financiële onderneming beslag kunnen leggen op het saldo van de rekening ten belope van hun vordering. ${ }^{44}$ Dit lijkt mij niet correct. De kwaliteitsrekening wordt immers niet aangehouden bij de financiële onderneming, maar bij de bank. De belanghebbende heeft een vordering op de financiële onderneming. Deze vordering wordt gedekt door de vordering van de financiële onderneming op de bank uit hoofde van de kwaliteitsrekening. In het kader van een verhaalsbeslag zal de belanghebbende zich op deze laatste vordering willen verhalen en dus derdenbeslag leggen onder de bank op het saldo van de kwaliteitsrekening. Het past mijns inziens niet bij de gekozen constructie om, naar analogie van het bepaalde in art. 25 lid 5 Wna en art. 19 lid 5 GDW, een bepaling in de wet op te nemen waarin een dergelijk beslag onder de bank wordt uitgesloten. Het ligt wel in de rede, om het verkeer op de rekening niet te frustreren, dat de belanghebbende zijn beslag beperkt tot het beloop van zijn vordering op de financiële onderneming.

Vorenstaande vraag moet worden onderscheiden van de vraag of een crediteur van een belanghebbende onder de bank beslag zal kunnen leggen op het saldo van de kwaliteitsrekening. Ik zou zeggen van niet. De bank is het saldo van de kwaliteitsrekening schuldig aan de financiële onderneming en niet aan de belanghebbende. Een beslag onder de bank zal dus geen doel treffen. Het is de financiële onderneming die een schuld heeft aan de belanghebbende. Een crediteur van de belanghebbende zal dus beslag moeten leggen onder de financiële onderneming.

\subsection{Opvorderbare gelden}

Art. 3:5 Wft verbiedt het aantrekken van opvorderbare gelden van het publiek, behoudens een daartoe strekkende vrijstelling of ontheffing. Art. 3:29c lid $2 \mathrm{Wft}$ bepaalt dat geldmiddelen die een betaalinstelling of EGI in verband met het verlenen van betaaldiensten van betaaldienstgebruikers ontvangt, in afwijking van art. 1:1 Wft, geen opvorderbare gelden zijn. Art. 3:29c lid $3 \mathrm{Wft}$ bepaalt hetzelfde voor geldmiddelen die door een EGI zijn ontvangen in ruil voor elektronisch geld.

43. Concept-MvT, p. 3 en 12.

44. Concept-MvT, p. 3 en 12.
Een dergelijke bepaling ontbreekt in de Wft voor afwikkelondernemingen en beleggingsondernemingen voor in verband met het verlenen van afwikkeldiensten respectievelijk beleggingsdiensten van derden ontvangen gelden. De Vrijstellingsregeling Wft bevat ook geen vrijstelling van art. 3:5 Wft voor afwikkelondernemingen en beleggingsondernemingen. $\mathrm{Zij}$ bevat wel een dergelijke vrijstelling voor notarissen en gerechtsdeurwaarders (art. 19 Vrijstellingsregeling), stichtingen derdengelden advocatuur (art. 20 Vrijstellingsregeling), niet-vergunningplichtige betaalinstellingen (art. 22 Vrijstellingsregeling), trustkantoren en stichtingen derdengelden trustkantoren (art. 23 en 24 Vrijstellingsregeling) en bewindvoerders (art. 24a Vrijstellingsregeling).

Ofschoon de door een afwikkelonderneming of een beleggingsonderneming gehouden derdengelden waarschijnlijk niet als opvorderbare gelden zullen kwalificeren omdat zij bestemd zijn om te worden doorbetaald of te worden omgezet in effecten, is het ter voorkoming van discussie wellicht toch raadzaam om ook voor afwikkelondernemingen en beleggingsondernemingen in een uitzondering op het verbod van art. 3:5 Wft te voorzien. Dit klemt te meer voor beleggingsondernemingen omdat de gelden bij beleggingsondernemingen mogelijk langer dan de in de parlementaire geschiedenis van de Wft genoemde veilige termijn van vijf kalenderdagen zullen uitstaan. ${ }^{45}$ Deze uitzondering zou kunnen worden bewerkstelligd door het opnemen in de Wft van een artikel met dezelfde strekking als art. 3:29c lid $2 \mathrm{Wft}$ of het opnemen van een vrijstelling in de Vrijstellingsregeling Wft vergelijkbaar met de hiervoor genoemde vrijstellingen. Een andere mogelijkheid zou zijn om in de memorie van toelichting bij het wetsvoorstel aan te geven dat in verband met het verlenen van afwikkeldiensten respectievelijk beleggingsdiensten door een afwikkelonderneming respectievelijk een beleggingsonderneming van derden ontvangen gelden geen opvorderbare gelden zijn. ${ }^{46}$ Uiteraard is het niet de bedoeling dat beleggingsondernemingen zich als banken kunnen gedragen en straffeloos gelden kunnen aanhouden die geen verband houden met het verlenen van beleggingsdiensten. Dit risico zou kunnen worden gemitigeerd door in de wet, de vrijstelling of de memorie van toelichting weer een termijn op te nemen waarbinnen de gelden uiterlijk moeten zijn doorbetaald of (her)belegd, welke termijn wat langer zou moeten zijn dan de genoemde termijn van vijf kalenderdagen. ${ }^{47}$

\section{Conclusie}

De voorgestelde regeling is mijns inziens niet veiliger, maar ook niet minder veilig dan de huidige wijzen van vermogens-

45. Kamerstukken II 2004/05, 29708, nr. 10, p. 229-230.

46. Vgl. art. 7:17 lid 1 onder b Nrgfo Wft, dat de mogelijkheid tot het inzetten van een stichting derdengelden door een beleggingsonderneming beperkt tot gelden bestemd voor de uitvoering van een transactie in financiële instrumenten.

47. Zie over deze problematiek W.A.K. Rank, Het verlenen van beleggingsdiensten en het verbod op het aantrekken van opvorderbare gelden, in: Bouwen en bezinning. Lustrumbundel 2007 Vereniging voor Effectenrecht, Deventer: Kluwer 2007, p. 261-278. 
scheiding. Daarnaast is het hanteren van een wettelijke kwaliteitsrekening juridisch niet minder complex dan het gebruik van een stichting derdengelden en mogelijk zelfs complexer. Waarschijnlijk is het hanteren van een wettelijke kwaliteitsrekening operationeel eenvoudiger dan het inzetten van een stichting derdengelden, maar heel veel verschil zal het niet maken. Toepassing van een wettelijke kwaliteitsrekening lijkt in ieder geval goedkoper dan gebruikmaking van een stichting derdengelden. De stichting derdengelden is echter alom tegenwoordig in de markt en heeft haar bruikbaarheid ruimschoots bewezen. Het ligt dan ook in de rede dat nieuwe partijen waarschijnlijk zullen opteren voor een constructie met een wettelijke kwaliteitsrekening, maar dat bestaande partijen hun huidige stichtingen derdengelden gewoon zullen continueren.

Het conceptwetsvoorstel is mijns inziens op diverse punten voor verbetering vatbaar. Te noemen zijn in dit verband het ontbreken van een geprivilegieerde status voor de restvordering op het overige vermogen van de financiële onderneming bij een tekort, van (operationele) regels ter voorkoming en aanzuivering van tekorten, van een nauwkeuriger bepaling van de op het afgescheiden vermogen verhaalbare vorderingen en van duidelijkheid omtrent de wijze van het effectueren van verhaal en de verhouding met het verbod op het aantrekken van opvorderbare gelden.

De toegevoegde waarde van het conceptwetsvoorstel is volgens mij vooral hierin gelegen dat het een praktisch alternatief biedt voor en naast de thans gebruikelijke wijzen van vermogensscheiding, in het bijzonder de stichting derdengelden. Of er bij banken in de praktijk veel animo zal bestaan om als aanbieders van kwaliteitsrekeningen te fungeren, staat nog te bezien. Veel banken hebben tot nu toe liever geen stichting derdengelden voor een financiële onderneming in de boeken. Hierbij speelt onder meer een rol dat de banken zich met het faciliteren van dergelijke stichtingen niet comfortabel voelen in het licht van de verplichtingen die op grond van de $\mathrm{Wwft}-$ de Wet ter voorkoming van witwassen en financieren van terrorisme - op hen rusten. Men denke aan cliëntenonderzoek en transactiemonitoring. Of dit anders zal zijn voor een kwaliteitsrekening valt moeilijk te voorspellen. Dat zich hier een nieuw verdienmodel aandient, lijkt mij echter niet waarschijnlijk. 